\title{
PHẪU THUẬT PHÌNH ĐộNG MẠCH CHỦ NGỰC VÕ̃ Ở BỆNH NHÂN TAKAYASU: NHÂN MỘT TRƯỜNG HợP LÂM SÀNG VÀ TỔNG QUAN Y VĂN
}

Lê Thành Khánh Vân*, Đoàn Văn Phụng*, Hồ Tất Bằng**, Phạm Hoàng Minh*, Trần Quyết Tiến***

\section{TÓM TẮT}

Một bệnh nhân nhỏ tuổi mắc Takayasu có túi phình động mạch chủ ngực xuống vỡ đã được phẫu thuật cấp cứu thành công, thay đoạn động mạch chủ xuống bằng ống ghép nhân tạo có sự hỗ trợ của hệ thống tuần hoàn ngoài cơ thể. Viêm động mạchTakayasu là một bệnh lý hiếm gặp ở trẻ em, giai đoạn sớm của bệnh thường biểu hiện triệu chứng lâm sàng và cận lâm sàng không đặc hiệu và khó chẩn đoán. Điều trị kịp thời bệnh sẽ ngăn chặn được diễn tiến mạn tính gây hẹp, tắc hoặc phình các mạch máu lớn dẫn đến những biến chứng nguy hiểm với tỷ lệ tử vong cao.

Tù khóa: Takayasu ở trẻ em, phình động mach chủ ngục

\section{SUMMARY \\ SURGICAL TREATMENT OF RUPTURED PSEUDOANEURYSM OF THE THORACIC AORTA DUE TO \\ TAKAYASU ARTERITIS : A CASE REPORT AND REVIEW LITERATURE}

Report a rare case of Takayasu: A 9 years old patient with a ruptured pseudoaneurysm of thoracic aorta due to Takayasu arteritis was sucessfully treated by open emerency surgery with circulation extracorporelle .Takayasu arteritis is a rare disease in children, the diagnosis is a challenge because the clinical and paraclinical are non- specific. Treatment is essential to prevent the insidios course and vascular damage: stenosis, occlusive lesions, aneurysms with dangerous complications and high rate of mortality.

Key word: Childhood Takayasu arteritis, thoracic pseudoaneurysms

\section{I. ĐẶT VẤN ĐỀ}

Bệnh viêm động mạch Takayasu là bệnh viêm ở các động mạch có kích thước lớn và vừa gây hẹp, tắc hoặc phình động mạch. Bệnh được bác sĩ nhãn khoa người Nhật Bản tên Mikito Takayasu mô tả lần đầu tiên năm 1908 ở bệnh nhân nữ, 21 tuổi có phình động mạch võng mạc và không có mạch quay [13].

Hẹp động mạch là một trong những tổn thương thường gặp nhất, chiếm $90 \%$ trong các bệnh nhân mắc Takayasu được báo cáo trong các y văn. Tuy vậy, phình động mạch cũng không phải hiếm gặp, theo ước tính, có khoảng $25 \%$ bệnh nhân Takayasu có tổn thương phình động mạch [6]. Phình động mạch chủ hoặc túi giả phình có nguy cơ tử vong cao do túi phình tăng kích thước và vỡ, theo ước tính tỉ lệ tử vong sau phẫu thuật ở những bệnh nhân có túi phình vỡ lên đến $50 \%[3]$.

Chúng tôi báo cáo một trường hợp bệnh nhân Takayasu 9 tuổi có túi phình động mạch chủ ngực vỡ được phẫu thuật cấp cứu thành công.

\section{TRƯỜNG HỢP LÂM SÀNG}

Bệnh nhân nam 9 tuổi , nhập Bệnh viện Chợ Rẫy ngày 14/12/2017.

Bệnh nhân không có tiền căn bệnh gì trước đây. Khởi bệnh trước nhập viện 1 tuần với triệu chứng đau tức ngực trái, ho và sốt nhẹ. Sau đó 2 ngày bệnh nhân bị ho ra máu đỏ tươi lượng ít lẫn

\footnotetext{
* Khoa HSPTT Trẻ em BV Chơ Rẫy

** Bộ môn phẫu thuật lồng ngực tim mạch- ĐH YD TP HCM *** Trung tâm tim mạch BV Chơ Rẫy

Ngườ chịu trách nhiệm khoa học: PGS.TS. Trần Quyết Tiến

Ngày nhận bài: 01/05/2018 - Ngày Cho Phép Đăng: 20/05/2018

Phản Biện Khoa học: PGS.TS. Đặng Ngọc Hùng
}

GS.TS. Lê Ngọc Thành 
đàm, nhập BV Nhi Đồng I. Tại BV Nhi Đồng I, bệnh nhân được chụp XQ ngực thẳng thấy mờ đồng nhất $1 / 3$ giữa phổi trái. Được chẩn đoán theo dõi viêm phổi hoại tử, chẩn đoán phân biệt Lao phổi bội nhiễm. Bệnh nhân được chụp cắt lớp vi tính, phát hiện túi phình động mạch chủ ngực vỡ/ Takayasu, sau đó chuyển Bệnh viện Chợ Rẫy.

\subsection{Khám lâm sàng:}

Sinh hiệu: Mạch 110 lần / phút, nhiệt độ 37 độ C, Huyết áp tay trái $125 / 85 \mathrm{mmHg}$, tay phải 120/90mmHg, 2 chân không đo được huyết áp.

- Bệnh nhân tỉnh, tiếp xúc được, da niêm nhạt.
- Than đau ngực trái nhiều.

- Mạch quay 2 bên bắt rõ, mạch 2 chân không bắt được.

- Tim nhanh đều, phổi trái giảm âm phế bào.

\subsection{Cận lâm sàng:}

\section{Công thức máu:}

- Hồng cầu :3.69 T/L, HCT 28.3\%, Hb 89 g/L

- Bạch cầu: 16 G/L, Neu 78.7\%, Tiểu cầu $233 \mathrm{G} / \mathrm{L}$

Sinh hóa máu: trong giới hạn bình thường.

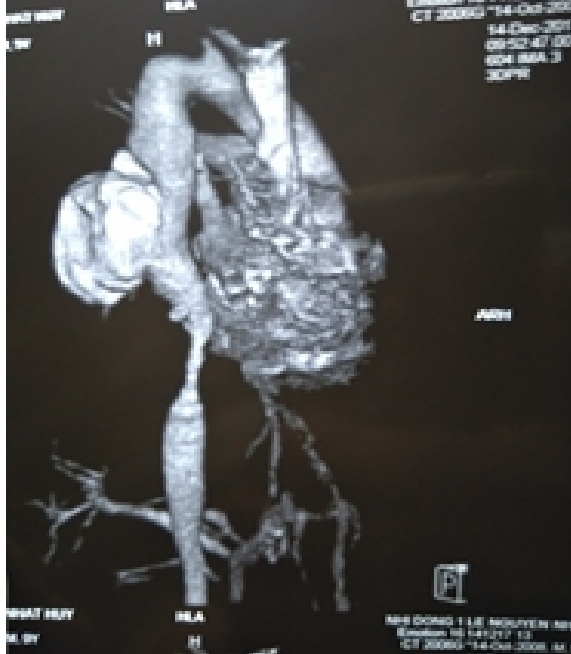

Hình 1: Hình ảnh CT trước mổ

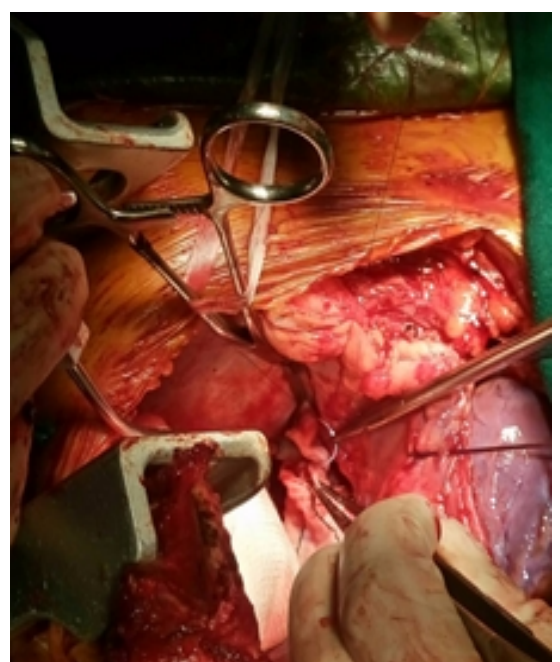

Hình 2: Hình ảnh trong mồ

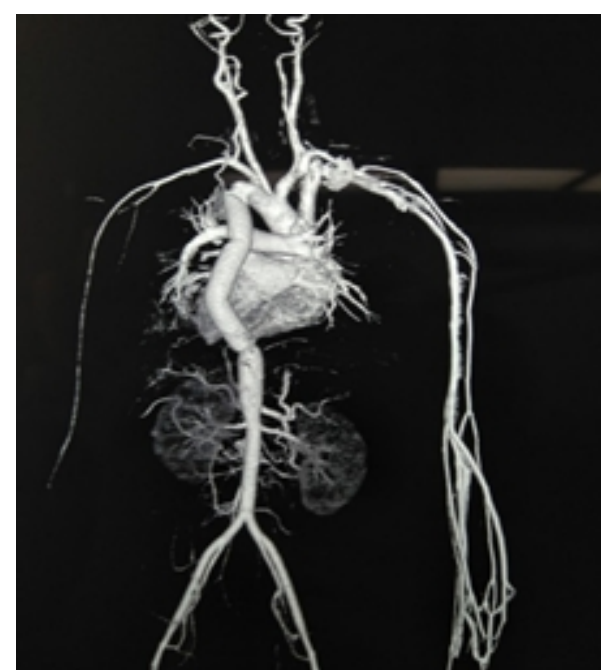

Hình 3: CT scan sau mổ

\section{Chẩn đoán hình ảnh:}

CT scan: - Động mạch chủ ngực xuống có túi giả phình đường kính $8 \mathrm{~cm}$, bờ túi phình không đều, động mạch chủ ngực dưới chỗ phình có đoạn hẹp khít, đoạn hẹp kéo dài $3 \mathrm{~cm}$.

- Tràn dịch màng phổi trái lượng nhiều.

- Tắc động mạch mạc treo tràng trên

Siêu âm tại giường cấp cứu:

- Túi phình động mạch chủ ngực xuống, có huyết khối thành, dày thất trái, tràn dịch màng ngoài tim lượng trung bình $\mathrm{EF}=56 \%$, tràn dịch màng phổi trái lượng nhiều

- Phình động mạch cảnh chung trái

- Xơ vữa động mạch chậu đùi 2 bên
2.3. Chẩn đoán: Phình động mạch chủ ngực xuống vỡ, hẹp nặng động mạch chủ ngực sau túi phình, phình động mạch cảnh chung trái, tắc động mạch mạc treo tràng trên/ Takayasu

Điều trị: Bệnh nhân được chỉ định phẫu thuật cấp cứu

- Mở ngực đường giữa xương ức, bộc lộ quai động mạch chủ và các nhánh, động mạch chủ ngực xuống ngay cổ trên túi phình. Đặt canule động mạch chủ, động mạch đùi phải, tĩnh mạch chủ trên và dưới. Chạy máy tuần hoàn ngoài cơ thể, hạ thân nhiệt 33 độ $\mathrm{C}$.

- Mở khoang màng phổi trái, thám sát thấy túi phình động mạch chủ ngực xuống phình lớn 
$12 \times 10 \mathrm{~cm}$ vỡ, máu cục khoang màng phổi trái lượng nhiều.

- Quyết định mở đường ngực trước bên trái, gian sườn V-VI, bộc lộ đoạn động mạch chủ ngực dưới chỗ hẹp. Kẹp động mạch chủ ngay sau chỗ chia động mạch dưới đòn trái và ngay dưới chỗ hẹp, thay đoạn động mạch chủ bằng ống ghép nhân tạo 16.

Thời gian kẹp động mạch chủ 45 phút, thời gian chạy tuần hoàn ngoài cơ thể 135 phút .

- Sau mổ bệnh nhân được điều trị Corticoid, kháng sinh, giảm đau, các thuốc hạ huyết áp

- Bệnh ổn định xuất viện ngày $2 / 1 / 2017$

- Kế hoạch điều trị tiếp theo: điều trị tiếp tục corticoid, điều trị tăng huyết áp, dự phòng và phát hiện sớm các biến chứng của Takayasu

- Kết quả chụp CTScan sau mổ: Các miệng nối không hẹp

- Kết quả giải phẫu bệnh lý: mẫu mô sinh thiết cho thấy xâm nhập tế bào lympho, mô bào, bạch cầu đa nhân trung tính. Thành động mạch loét, xâm nhập tế bào viêm, lympho bào

\section{BÀN LUẬN}

Bệnh viêm động mạch Takayasu là bệnh lý viêm mạn tính động mạch chủ và các nhánh chính của nó, cũng có thể bao gồm động mạch phổi hoặc động mạch vành. Bệnh hiếm gặp ở trẻ em[7], hậu quả của quá trình viêm mạch máu có thể dần đến những dạng tổn thương khác nhau như hẹp, tắc, phình động mạch. Nguyên nhân và sinh bệnh học của bệnh viêm mạch Takayasu đến nay vẫn chưa được biết rõ kể từ những mô tả đầu tiên vào năm 1908 của bác sĩ nhãn khoa người Nhật Bản. Bài báo này chúng tôi tập trung đề cập đến những đặc điểm của bệnh viêm động mạch Takayasu ở trẻ em.

\subsection{Dịch tễ học và bệnh nguyên}

Viêm động mạch Takayasu được gặp phải trên toàn thế giới nhưng phổ biến nhất là ở Châu Á, châu Phi và Mỹ La Tinh [8]. Bệnh này là nguyên nhân hàng đầu gây tăng huyết áp do hẹp động mạch thận ở trẻ em châu Á[2]. Theo một nghiên cứu có tính hệ thống ở Nhật Bản từ năm 1982 đến 1984, có khoảng 2600 bệnh nhân mắc Takayasu [12]. Tỷ lệ mới mắc bệnh ở Mỹ là 2,6/1.000.000 dân mối năm[4].
Bệnh này thường gặp phần lớn ở người trẻ tuổi, độ tuổi thường mắc là 20 đến 30 tuổi. Tuổi khởi phát bệnh có thể sớm hơn nhưng hiếm gặp ở trẻ nhỏ. Tỷ lệ nam :nữ là $1: 9$ trong một nghiên cứu từ Nhật[12]. Tại Việt Nam, một nghiên cứu trên trẻ em tại bệnh viện Nhi Đồng I năm 2003, tỷ lệ nam :nữ là 1:1,63 [9]

Bệnh học Takayasu không được hiểu nhiều, các tế bào trung gian miễn dịch đóng một vai trò quan trọng trong cơ chế tổn thương mạch máu. Đặc trưng bởi đáp ứng miễn dịch tế bào, bao gồm lympho $\mathrm{T}$, tế bào trình diện kháng nguyên, đại thực bào. Không có bằng chứng của tự kháng thể, tế bào $\mathrm{B}$ và các bổ thể. Yếu tố di truyền có một vai trò trong bệnh sinh, ở Nhật Bản và Hàn Quốc bệnh liên quan đến HLA A10, B5, BW52, RR2, DR4, ở Mỹ thì HLA B22 [14]. Một số nghiên cứu cho thấy có mối liên quan mật thiết giữa bệnh Lao và Takayasu, bên cạnh đó vùng dịch tễ của Lao và Takayasu có sự tương đồng. Tại Việt Nam, nghiên cứu của bệnh viện Nhi Đồng I năm 2003 cho thấy có $23,8 \%$ bệnh nhân Takayasu bị bệnh Lao hoặc gia đình có người thân mắc bệnh Lao[9].

Về mô bệnh học, cơ bản gồm pha cấp: viêm động mạch ở lớp áo ngoài và giữa với sự thâm nhiễm của tế bào lympho $T$ và đại thực bào sau đó thâm nhiễm vào lớp áo trong. Pha mạn tính: tiến triển dày thành động mạch gây hẹp: lớp áo ngoài xơ hóa, lớp áo giữa bị phá hủy và tăng sinh cơ của lớp áo trong. Quá trình này diễn tiến dần dần gây hẹp, tắc hoặc phình động mạch[7]

\subsection{Triệu chứng lâm sàng và chẩn đoán}

Biểu hiện lâm sàng của bệnh có thể chia làm 3 giai đoạn: giai đoạn đầu tiên triệu chứng lâm sàng không đặc hiệu như: sốt, giảm cân, nhức đầu, mệt, đổ mồ hôi về đêm... Giai đoạn thứ hai là giai đoạn mạch máu bao gồm triệu chứng của hẹp, tắc hoặc phình động mạch. Giai đoạn thứ 3 là giai đoạn thuyên giảm một phần triệu chứng lâm sàng. Tuy nhiên, các giai đoạn lâm sàng thường chồng chéo lên nhau khó phân biệt rõ[5].

Nghiên cứu về Takayasu ở trẻ em Việt Nam năm 2003 của nhóm nghiên cứu BV Nhi Đồng I đã liệt kê các triệu chứng thường gặp với tần suất cụ thể ở bảng 1 . 
Bảng 1: Các triệu chứng lâm sàng thường gặp[9]

\begin{tabular}{|l|c|l|c|}
\hline Triệu chứng & Tỷ lệ \% & Triệu chứng & Tỷ lệ \% \\
\hline Nhức đầu & 47.6 & Tình cờ phát hiện & 9,5 \\
\hline Đau bụng, ói & 23.8 & Tăng huyết áp & 95 \\
\hline Chảy máu cam & 23,8 & Thay đổi huyết áp & 90 \\
\hline Khó thở & 23,8 & Thay đổi mạch & 71 \\
\hline Mệt mỏi & 19 & Âm thồi & 38 \\
\hline Chóng mặt & 9,5 & Suy tim & 19 \\
\hline Xanh xao & 9,5 & Phù & 9,5 \\
\hline Bỏ ăn & 9,5 & Nồi mẩn da & 9,5 \\
\hline Ho & 9,5 & Viêm khớp & 9,5 \\
\hline
\end{tabular}

\section{Tiêu chuẩn chẩn đoán}

Năm 2010, Liên đoàn chống Thấp khớp Châu Âu ( EULAR), Tổ chức thử nghiệm nhi khoa Thấp khớp quốc tế ( PRINTO), Hội Thấp khớp nhi khoa Châu Âu (PRES) đã đưa ra đồng thuận về tiêu chuẩn chẩn đoán viêm mạch Takayasu ở trẻ em (Bảng 2) bao gồm 1 tiêu chuẩn chính và 5 tiêu chuẩn phụ, chẩn đoán xác định khi có tiêu chuẩn chính và ít nhất 1 tiêu chuẩn phụ [11].

Bảng 2: Tiêu chuẩn chẩn đoán Takayasu trẻ em theo EULAR/PRINTO/PRES 2010

\begin{tabular}{|c|c|c|}
\hline $\begin{array}{l}\text { Tiêu } \\
\text { chuẩn } \\
\text { chính }\end{array}$ & $\begin{array}{l}\text { 1. Bất thường về mặt hình ảnh học } \\
\text { (CT Scan, MRI, PES) của động mạch } \\
\text { chủ hoặc các nhánh của nó hoặc } \\
\text { động mạch phổi. }\end{array}$ & $\begin{array}{l}\text { Dãn, phình, hẹp, tắc hoặc dày thành mạch mà } \\
\text { không do các nguyên nhân khác. }\end{array}$ \\
\hline \multirow{5}{*}{$\begin{array}{l}\text { Tiêu } \\
\text { chuẩn } \\
\text { phụ }\end{array}$} & 1. Mất mạch/ đau cách hồi & $\begin{array}{l}\text { Mạch ngoại biên không bắt được, yếu hoặc không } \\
\text { đều nhau } \\
\text { Đau cách hồi: đau cơ tăng lên sau vận động }\end{array}$ \\
\hline & 2. Chênh lệch huyết áp & Chênh lệch huyết áp tứ chi > 10mmHg \\
\hline & 3. Tiếng thổi bất thường & $\begin{array}{l}\text { Nghe được tiếng thổi hoặc sờ thấy rung ở các mạch } \\
\text { máu lớn }\end{array}$ \\
\hline & 4. Tăng huyết áp & $\begin{array}{l}\text { Huyết áp tâm /tâm trương }>95^{\text {th }} \text { bách phân vị theo } \\
\text { chiều cao }\end{array}$ \\
\hline & 5.Xét nghiệm & Tốc độ lắng máu > 20mm/giờ hoặc CRP tăng. \\
\hline
\end{tabular}

Bệnh nhân sau khi được chẩn đoán viêm động mạch Takayasu được xếp tổn thương động mạch theo hội nghị quốc tế về Takayasu tổ chức tại Tokyo năm 1994( bảng 3). 
Bảng 3: Phân loại tổn thương động mạch ở bệnh nhân Takayasu - Tokyo 1994[7]

\begin{tabular}{|c|c|c|c|c|}
\hline Type & Tổn thương động mạch & & & \\
\hline $\mathrm{I}$ & Nhánh của cung động mạch chủ & & & \\
\hline IIa & $\begin{array}{l}\text { Động mạch chủ lên, cung động mạch } \\
\text { chủ và các nhánh của nó }\end{array}$ & & & \\
\hline $\mathrm{IIb}$ & $\begin{array}{l}\text { Động mạch chủ lên, cung động mạch } \\
\text { chủ và các nhánh của nó, động mạch } \\
\text { chủ ngực xuống }\end{array}$ & Type I & Type lla & Type Illb \\
\hline III & $\begin{array}{l}\text { Động mạch chủ xuống đoạn ngực, bụng } \\
\text { và/hoặc động mạch thận }\end{array}$ & & & \\
\hline IV & $\begin{array}{l}\text { Động mạch chủ bụng và / hoặc động } \\
\text { mạch thận }\end{array}$ & & & \\
\hline $\mathrm{V}$ & Phối hợp type IIb và IV & Type III & Type IV & Type V \\
\hline
\end{tabular}

Mặc dù thế giới đã đưa ra những đồng thuận về tiêu chuẩn chẩn đoán, phân loại nhưng cho đến hiện nay, việc chẩn đoán Takayasu ở trẻ em vẫn còn là một thách thức vì có một số lượng lớn các bệnh cần phải chẩn đoán phân biệt. Hơn nữa, trong giai đoạn cấp, triệu chứng lâm sàng thường không đặc hiệu và những xét nghiệm dấu ấn sinh học của Takayasu độ nhạy thấp và không được phổi biến. Những triệu chứng lâm sàng như sốt, đổ mồ hôi trộm ban đêm, sụt cân, đau khớp, đau cơ, đau bụng, đau đầu, thiếu máu và những triệu chứng cận lâm sàng như tốc độ lắng máu thường phổ biến trong rất nhiều bệnh.

Việc chậm trễ trong chẩn đoán giai đoạn cấp thường dẫn đến bệnh tiến triển sang giai đoạn mạn tính gây hẹp lòng mạch và gây ra các biến chứng khác[10].

\section{3. Điều trị nội khoa}

Liệu pháp corticoid có hoặc không có tác nhân độc tế bào

- Corticoid là điều trị chính: đường uống, liều $1 \mathrm{mg} / \mathrm{kg} / \mathrm{ngày}$, giảm liều dần sau vài tuần đến vài tháng khi các triệu chứng thuyên giảm. Nên dùng ở liều thấp kéo dài và lưu ý các tác dụng phụ của thuốc, nên điều trị dự phòng loãng xương phối hợp

- Các tác nhân độc tế bào dùng cho bệnh nhân đề kháng corticoid hoặc bệnh tái phát. Dùng kéo dài ít nhất 1 năm sau khi bệnh thuyên giảm, sau đó giảm dần liều rồi ngưng. Bao gồm: Methotrexate ,5-25 mg/ tuần bằng đường uống, Azathioprine $1-2 \mathrm{mg} / \mathrm{kg} / \mathrm{ngày}$ đường uống, Cyclophosphamide $2 \mathrm{mg} / \mathrm{kg} /$ ngày đường uống[1]

- Kiểm soát các yếu tố nguy cơ như: rối loạn lipid, tăng huyết áp là bắt buộc để giảm các biến chứng tim mạch (là nguyên nhân chính gây tử vong). Ngoài ra liều thấp Aspirin có thể có hiệu quả trong viêm các mạch máu lớn

\section{4. Điều trị ngoại khoa}

Các trường hợp tắc hoặc hẹp mạch hoặc phình động mạch nên được nong mạch hoặc phẫu thuật khi bệnh hồi phục, các chỉ định bao gồm:

- Hẹp ĐM thận gây tăng huyết áp

- Hẹp ĐM vành gây thiếu máu cơ tim

- Khập khiễng cách hồi ở chi có ảnh hưởng đến hoạt động hằng ngày

- Thiếu máu não cục bộ và hoặc hẹp quan 
trọng của 3 hoặc nhiều hơn các mạch máu não

- Có trào ngược ĐM chủ

- Phình ĐM chủ ngực bụng mà đường kính > 1.5 lần đường kính bình thường

- Hẹp nặng ĐM chủ

\subsection{Theo dõi điều trị}

Kerr và cộng sự đã đưa ra các tiêu chuẩn để đánh giá hoạt động bệnh. Khi xuất hiện mới hoặc tiến triển xấu của 2 hoặc nhiều hơn các triệu chứng sau chứng tỏ bệnh đang có diển tiến xấu [7]:

- Các triệu chứng toàn thân: sốt, đau khớp mà không rõ nguyên nhân

- VS tăng

- Triệu chứng thiếu máu cục bộ hoặc viêm mạch máu như: khập khiễng cách hồi, mạch yếu hoặc vô mạch, nghe tiếng thổi theo ĐM, huyết áp chênh lệch ở 2 tay hoặc 2 chân hoặc cả tay và chân

- Hình ảnh chụp mạch điển hình có các tổn thương mạch máu mới

\section{KẾT LUẬN}

Viêm động mạchTakayasu là một bệnh lý hiếm gặp ở trẻ em, giai đoạn sớm của bệnh thường biểu hiện triệu chứng lâm sàng và cận lâm sàng không đặc hiệu và khó chẩn đoán. Điều trị kịp thời bệnh sẽ ngăn chặn được diễn tiến mạn tính gây hẹp, tắc hoặc phình các mạch máu lớn dẫn đến những biến chứng nguy hiểm với tỷ lệ tử vong cao.

\section{TÀI LIỆU THAM KHẢO}

1. Chatterjee, Soumya, et al. (2014), "Clinical Diagnosis and Management of Large Vessel Vasculitis: Takayasu Arteritis", Current Cardiology Reports.

2. Chugh KS, Sakhuja V. (1992), "Takayasu's arteritis as a cause of renovascular hypertension in Asian countries", Am J nephrol. 306, pp. 464-465.

3. Davis FM, Rateri DL, Daugherty A (2014), "Mechanisms of aortic aneurysm formation: translating preclinical studies into clinical therapies.", Heart 100, pp. 1498 - 505.

4. Hall S, Barr W, Lie JT. (1985), "Takayasu arteritis. A study of 32 North American patients.", Medicine (Baltimore). 64, pp. 89-99.

5. Inder SJ, Bobryshev $\mathrm{YV}$, Cherian SM, Lord RS, Masuda K, and C, Yutani (2000), " Accumulation of lymphocytes, Dendritic cells, and granulocytes in th aortic wall affected by Takayasu's arteritis.", Angiology. 51, pp. 565-79.

6. JC., Mason (2010), "Takayasu arteritisadvances in diagnosis and management.", Nat Rev Rheumatol 6, pp. 406-15.

7. Kerr GS, Hallahan CW, Giordano J, et al. (1994), "Takayasu arteritis", Ann Intern Med 120, pp. 919-929.

8. Lande A, Bard R, Rossi P, Passariello R, Castrucci A. (1976), "Takayasu's arteritis. A worldwide entity", NY State J Med. 32, pp. 379-392.

9. Lê Huy Thạch, Võ Công Đồng, Đỗ Văn Dũng (2003), "Những đặc điểm bệnh Takayasu ở trẻ em Việt Nam từ 1998-2002", Y học TP Hồ Chí Minh. 7, pp. 112-118.

10. Marisa Di Santo, Erica V. Stelmaszewski, Alejandra Villa (2017), "Takayasu arteritis in paediatrics", Cardiology in the Young

11. Ozen S, Pistorio A, Iusan SM, et al. : Ankara 2008. Part II: final classification criteria. (2010), "EULAR/PRINTO/PRES criteria for HenochSchönlein purpura, childhood polyarteritis nodosa, childhood Wegener granulomatosis and childhood Takayasu arteritis", Ann Rheum Dis. 69, pp. 798-806.

12. Sekiguchi M, Sazuki J. (1992), "An overview of Takayasu Arteritis", Heart Vessels, pp. 6-10.

13. Takayasu.M (1908), "A case with unusual changes of the central vessel in the retina.", Nippon Ganka Gakkai Zasshi. . 12, pp. 554-7.

14. Weyand CM, Goronzy JJ. (2003), "Medium- and large-vessel vasculitis", Engl J Med. 2(349), pp. 160-9. 